\title{
Pengenalan Aktivitas Manusia Melalui Analisis Data Gerakan Smartphone
}

\author{
Eunike Endariahna S ${ }^{1}$, Andes Suciani ${ }^{2}$, Philipus Silaen ${ }^{3}$, Septian Adiwibowo ${ }^{4}$ \\ ${ }^{1,2,3,4}$ Fakultas Ilmu Komputer, Program Studi Magister Teknologi Informasi, Universitas Indonesia, Jakarta, \\ Indonesia \\ ${ }^{1}$ Fakultas Teknik dan Informatika, Program Studi Informatika, Universitas Multimedia Nusantara, Tangerang, \\ Indonesia \\ 12eunike.endahriana@umn.ac.id, ${ }^{2}$ andes.suciani@ui.ac.id, ${ }^{3}$ philipus.silaen@ui.ac.id, ${ }^{4}$ septian.adibowo@ui.ac.id
}

Diterima 18 Mei 2021

Disetujui 16 Juni 2021

\begin{abstract}
Technology whose benefits are felt by humans from the development of cellular telephones is the birth of smart phones or smartphones. . The development of smartphone integration is growing very rapidly. Today's smartphones are not only communication tools but now offer many features and deployment of sensors. Smartphones are also designed to track the user's daily activities, learn and then help the user to make better decisions about what the user will take in the future. Applications that utilize the movement of a smartphone to analyze human activity are used by the Moves app, Fitbit Charge, Nike Fuelband, Apple Watch Health app. To perform human motion recognition activities, data is generated and collected from smartphones such as iPhones and Androids, or wearables such as the Apple Watch smartwatch, Nike Fuelband, and Fitbit Charge. Today the technology industry has succeeded in producing good quality devices at low prices. Sensors commonly used to collect data include an accelerometer, gyroscope, heart rate monitor, and thermometer. This study collects and manages data from the use of sensors on smartphones. The resulting data also combines these sensors with a magnetometer and GPS. So that we can find out the position, distance and number of points from using smart devices. The resulting data is very large, fast and real time data or what is called big data. Then these large data sets can produce complex and unstructured data. The processing requires more difficult and large computations and storage to produce useful data sets. The resulting benefits can provide problem solutions, business benefits and even new business opportunities. The resulting data can be used to seek opportunities for the benefits of human movement. The tangible benefits that can be provided are Monitoring city prisoners for government, community grouping, city density detection and distribution maps that can be used by business opportunities such as retail or banks.
\end{abstract}

Index Terms-Accelerometer, Big Data Analytics, Human Movement Recognition Activity, Gyroscope, Heart Rate Monitor, Thermometer.

\section{Pendahuluan}

Tujuan dari diciptakannya teknologi adalah memberikan kemudahan dan kenyaman untuk membantu manusia. Salah satu teknologi yang manfaatnya sangat dirasakan oleh manusia dari perkembangan telepon seluler adalah lahirnya telepon pintar atau smartphone. Di awal tahun 2000, belum banyak yang memiliki telepon pintar di Indonesia. Ketika itu, telepon pintar masih dianggap sebagai keperluan sekunder bahkan tersier oleh sebagian kalangan. Kini keadaannya telah berbeda, telepon pintar telah berubah menjadi kebutuhan primer yang dimiliki oleh setiap orang. Di Indonesia sendiri, negara ini berada di urutan ke enam dengan jumlah penduduknya diperkiraan sebanyak 261 juta jiwa, telah menggunakan telepon sebanyak 236 juta unit [1].

Telepon pintar kini menawarkan banyak fitur lain seperti multitasking dan penyebaran berbagai sensor, di samping sebagai alat komunikasi. Integrasi perangkat mobile ini dalam kehidupan kita sehari-hari berkembang pesat. Smartphone juga dirancang untuk melacak kegiatan penggunanya setiap hari, belajar dan kemudian membantu pengguna untuk membuat keputusan yang lebih baik mengenai tindakan yang dilakukan pengguna di masa mendatang [2]. Dengan memanfaatkan gerakan dari smartphone untuk menganalisa aktivitas manusia yang digunakan oleh Moves app, Fitbit Charge, Nike Fuelband, Apple Watch Health app.

Aplikasi-aplikasi ini mendapatkan data dari jenis sensor terdapat pada smartphone seperti accelerometer, gyroscope, sensor tekanan, sensor cahaya. Accelerometer merupakan sensor yang sudah menjadi fitur standar atau harus ada dari smartphone. Accelerometer merupakan elemen sensor yang mengukur percepatan, sudut kemiringan, tanjakan, rotasi, benturan, vibrasi dan gravitasi. Kegunaannya bisa mendukung berbagai kegiatan pengguna seperti: membaca, bermain game, olahraga dan berbagai aktivitas lainnya. Contohnya adalah Moves app dari gerakan yang dihasilkan pengguna, aplikasi ini bisa mengetahui pengguna sedang jalan, lari pelan, lari sprint, bersepeda, naik tangga, turun tangga, naik kendaraan bermotor atau sedang dalam perjalanan di pesawat. Keuntungan dari data yang diolah aplikasi ini 
membantu pengguna dalam meningkatkan kesehatan seperti menghitung jumlah langkah setiap hari. Pengguna dapat melacak area yang sudah ditempuh saat berolahraga atau pun lokasi yang dia datangi setiap harinya. Berikut Gambar 1. adalah perbandingan Moves app dengan aplikasi fitnes lainnya:

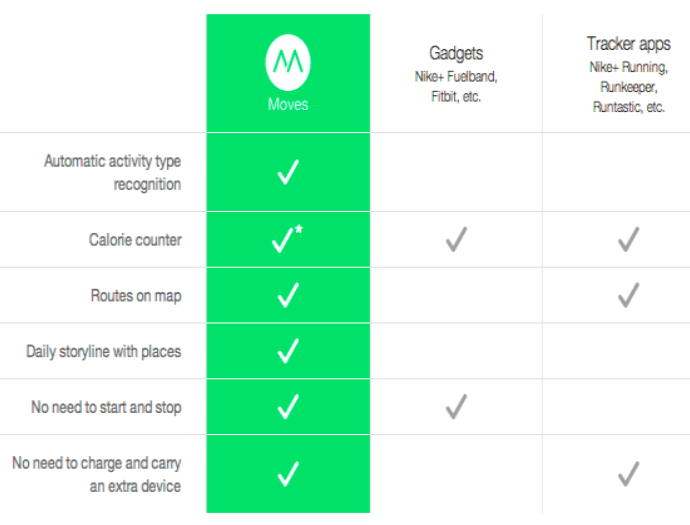

Gambar 1. Perbandingan Moves App dengan Aplikasi Fitnes Lainnya [3]

Dalam penelitian ini, kami akan meneliti lebih lanjut perkembangan data yang bisa dimanfaatkan dari gerakan smartphone oleh pengguna setiap harinya. Aktivitas manusia setiap harinya akan terus bertumbuh dan menjadi big data. Cara mendapatkan data dari sensor smartphone kemudian diolah menggunakan metode machine learning agar menghasilkan informasi yang lebih berguna untuk kedepannya.

\section{Metode PenElitian}

Untuk melakukan aktivitas pengenalan gerakan manusia, data dihasilkan dan dikumpulkan dari telepon pintar seperti iPhone dan Android, atau peralatan yang dapat dipakai seperti jam tangan pintar Apple Watch, Nike Fuelband, dan Fitbit Charge (Gambar 2) [4]. Sensor yang biasa digunakan untuk mengumpulkan data di antaranya adalah accelerometer, gyroscope, monitor detak jantung, dan termometer. Metode lain juga mengkombinasikan sensor-sensor ini dengan magnetometer dan GPS (Global Positioning System). [2]

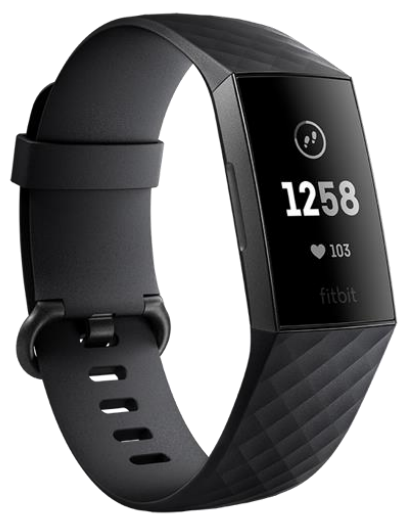

Data yang dihasilkan dari peralatan sensor ini berbentuk time series data, yaitu data yang berbentuk banyak titik data yang diurutkan berdasarkan ukuran waktu. Time series data ini diambil secara berurutan dengan rentang waktu atau frekuensi yang konsisten. Agar bisa mendapatkan konteks informasi, data jenis ini harus diperlakukan sebagai sebuah urutan data dan tidak bisa diperlakukan sebagai titik-titik data yang terpisah [6]. Contoh bentuk time series data yang umum digunakan adalah data pergerakan harga stok saham yang konteks informasinya baru bisa didapatkan apabila data ditampilkan dan diurutkan dalam suatu periode (Gambar 3).

Bab ini akan menjelaskan mengenai dua alat sensor utama yang digunakan untuk mengumpulkan data gerakan manusia, yaitu accelerometer dan gyroscope beserta contoh format data dari masingmasing peralatan tersebut. Berikutnya teknik-teknik pembersihan data (data cleaning) dan persiapan data (data preparation) yang umum dilakukan untuk kedua sensor ini akan dijabarkan. Pembahasan akan menitikberatkan ke riset utama yang dibahas di tulisan ini, yaitu penelitian dari Anguita, Ghio, Oneto, LlanasParra, \& Reyes-Ortiz [2].

\section{CSCO - Cisco Systems (2003 - 2013) Closing Price Time Series}

Gambar 3. Time Series Data Pergerakan Harga
Saham [7]

\section{A. Accelerometer}

Accelerometer adalah alat untuk mengukur akselerasi atau percepatan, yaitu menghitung berapa banyak kecepatan suatu benda berubah dalam suatu rentang waktu [8]. Menggunakan prinsip tersebut, accelerometer bisa memberikan informasi mengenai perubahan arah dan pergerakan suatu benda.

Pada awalnya, accelerometer digunakan di pesawat luar angkasa (space shuttle) untuk mengukur perubahan kecepatan roket pesawat, mengukur apogee (ketika pesawat berada di titik terjauh dari bumi sehingga pengaruh akselerasi karena gravitasi berada di titik paling rendah), dan mengukur orientasi pesawat dengan cara mendeteksi sisi tekanan gravitasi bumi ketika pesawat berubah arah.

Gambar 2. Jam Tangan Pintar Fitbit Charge [5] 
Penggunaan lain accelerometer di kehidupan sehari-hari antara lain di sistem kantung udara mobil untuk menyelamatkan supir dan penumpang dari kecelakaan. Ketika mobil mengalami tabrakan, maka accelerometer akan mendeteksi perubahan kecepatan yang sangat mendadak dan memicu dibukanya kantung udara untuk mencegah benturan penumpang ke sisi dashboard mobil.

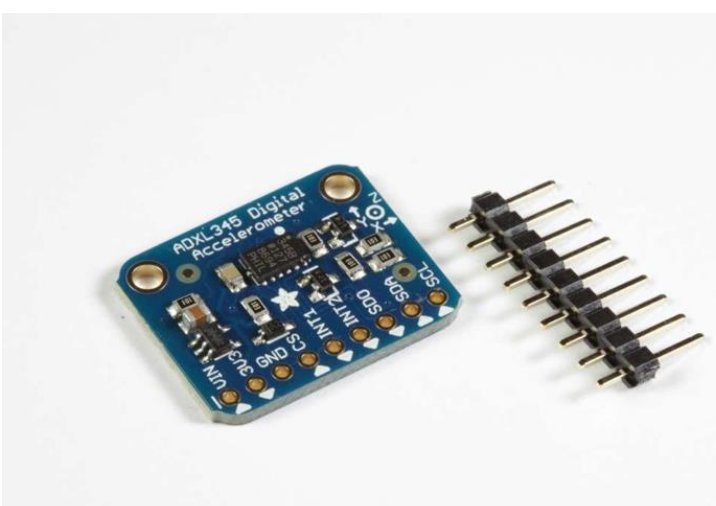

Gambar 4. Digital Accelerometer [9]

Gambar 4 menunjukkan digital accelerometer yang biasa digunakan di smartphone dan smartwatch. Sensor akselerasi di dalam digital accelerometer menggunakan silicon wafer yang ditopang oleh silicon spring. Apabila terjadi perubahan gerakan, maka silicon wafer ini akan mendapatkan tekanan dari arah sumbu X, Y, atau Z. Tekanan ini akan diterjemahkan ke dalam perbedaan kapasitansi, dan dapat diukur dalam perubahan satuan tegangan. Dari pengukuran ini, accelerometer akan memberikan perubahan informasi dari tiga arah, yaitu sumbu X, Y, dan Z [9].

Sebagai penghasil time series data, accelerometer mengenal konsep frekuensi, yaitu setiap berapa periode waktu sensor ini menangkap data. Semakin besar frekuensi maka akan semakin akurat data akselerasi yang dihasilkan, namun akan menghasilkan jumlah data yang lebih banyak. Gambar 5 menunjukkan contoh data set yang dihasilkan oleh sebuah accelerometer dengan frekuensi $400 \mathrm{~Hz}$, yang artinya sensor ini akan menangkap data sebanyak 400 kali dalam setiap detiknya. Data yang dihasilkan adalah perubahan percepatan dari sisi sumbu X, Y, dan $\mathrm{Z}$, sehingga setiap titik data yang dihasilkan oleh accelerometer selalu menghasilkan tuplet berisi tiga nilai angka.

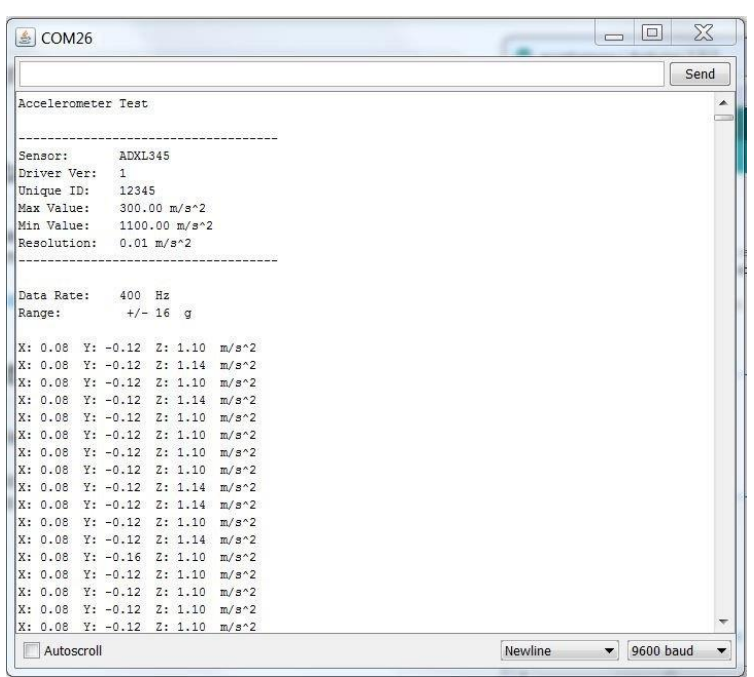

Gambar 5. Data Accelerometer [9]

Tantangan utama dalam mengolah data dari accelerometer selain besarnya jumlah data adalah banyaknya noise dari data yang dihasilkan [10]Beberapa teknik pengurangan noise untuk data yang dihasilkan dari accelerometer adalah Kalman Filtering Algorithm [11]), Singular Value Decomposition dikombinasikan dengan SavitzkyGolay Filter [12] atau Low Pass Filter [13]

\section{B. Gyroscope}

Gyroscope adalah alat sensor yang memanfaatkan gravitasi bumi untuk menentukan orientasi benda. Gyroscope didesain menggunakan cakram yang bisa berputar secara bebas (disebut juga rotor) yang dipasang di cakram yang lebih besar lagi. Ketika sumbu gyroscope berputar, rotor ini tetap diam di tempatnya dan tetap stabil menunjuk ke arah di mana gravitasi berasal. Secara singkat, tujuan utama gyroscope adalah menunjukkan ke mana arah "bawah" [14]. Prinsip gyroscope tradisional ditunjukkan di Gambar 6. di mana pergerakan apapun akan tetap mengarahkan rotor ke posisi dari mana gravitasi bumi berasal.

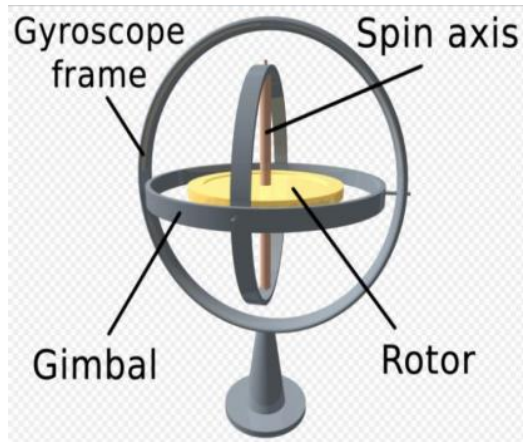

Gambar 6. Prinsip Gyroscope Tradisional [15]

Dalam aplikasi sehari-hari, gyroscope digunakan sebagai altimeter di pesawat, helikopter, dan drone untuk menjaga orientasi mereka agar tetap menghadap ke atas. Stasiun ruang angkasa MIR dan teleskop ruang 
angkasa Hubble memiliki banyak gyroscope untuk menjaga orientasi mereka terhadap matahari [15].

Digital gyroscope (Gambar 7.) tidak memiliki roda bergerak, melainkan menggunakan 3 buah struktur tuning fork yang terbuat dari silicon wafer. Mereka akan bergetar bila distimulasi dengan sinyal elektrik. Ketika sumbu pergerakan benda diputar, tuning fork ini akan merasakan tekanan dikarenakan gaya Coriolis. Perbandingan tekanan ini proporsional dengan kecepatan rotasi benda. Ketiga buah tuning fork ini disusun secara ortogonal masing-masing untuk merepresentasikan sumbu X, Y, dan Z. Perputaran gyroscope akan direpresentasikan ke dalam data rotasi degrees-per-second untuk masing-masing sumbu tersebut [9] Sama seperti accelerometer yang pengambilan datanya menggunakan pola frekuensi, data yang dihasilkan dari gyroscope juga berbentuk time series data.

Meskipun sekilas mirip, perbedaan utama antara accelerometer dengan gyroscope adalah accelerometer tidak dapat mendeteksi rotasi. Accelerometer berguna untuk mendeteksi perpindahan, tetapi gyroscope bisa mendeteksi apabila rotasi terjadi tanpa perpindahan (hal yang tidak bisa dideteksi oleh accelerometer). Penggunaan keduanya secara bersamaan di smartphone dan smartwatch dalam frekuensi yang sama akan melengkapi satu sama lain untuk menghasilkan dataset yang bisa dianalisis dalam pengenalan aktivitas manusia.

Tabel 1. Protokol Percobaan [2]

\begin{tabular}{|c|l|c|c|l|c|}
\hline No. & Static & Time (sec) & No. & Dynamic & Time (sec) \\
\hline 0 & Start (Standing Pos) & 0 & 7 & Walk (1) & 15 \\
1 & Stand (1) & 15 & 8 & Walk (2) & 15 \\
2 & Sit (1) & 15 & 9 & Walk Downstairs (1) & 12 \\
3 & Stand (2) & 15 & 10 & Walk Upstairs (2) & 12 \\
4 & Lay Down (1) & 15 & 11 & Walk Downstairs (1) & 12 \\
5 & Sit (2) & 15 & 12 & Walk Upstairs (2) & 12 \\
6 & Lay Down (2) & 15 & 13 & Walk Downstairs (3) & 12 \\
& & 14 & Walk Upstairs (3) & 12 \\
& & 15 & Stop & 0 \\
\hline
\end{tabular}

Basis data yang diperoleh dipartisi menjadi data pelatihan dan data tes dalam proporsi $70 \%$ hingga $30 \%$. Partisi diacak tetapi dipastikan bahwa tidak ada sampel yang berasal dari pengguna yang sama di kedua himpunan bagian. Data pelatihan digunakan untuk melatih Multiclass SVM classifiers. Percobaan diimplementasikan menggunakan smartphone Samsung Galaxy S II dilengkapi dengan baterai Li-Ion $1650 \mathrm{mAh}$ dengan pengoperasian siaga hingga 610 jam dan sistem operasi Android Gingerbread versi 2.3.4.

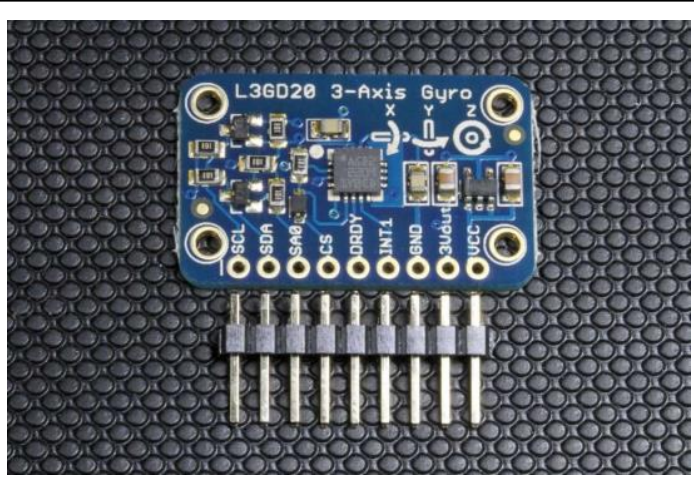

Gambar 7. Digital Gyroscope [16]

\section{Koleksi dan Pembersihan Data}

Pada Riset Anguita, Ghio, Oneto, Llanas-Parra, \& Reyes-Ortiz uji coba dilakukan dengan membuat dan mengembangkan dataset pengenalan aktivitas manusia dengan total sukarelawan yang berpartisipasi yaitu 30 orang dengan usia 19 hingga 48 tahun [2]. Penelitian dilakukan dengan mengumpulkan rangkaian gerakan yang terdiri dari 6 usulan Activities of Daily Living (ADL) (berdiri, duduk, berbaring, berjalan, berjalan ke atas dan berjalan turun). Setiap subjek melakukan protokol percobaan dua kali, dan setiap aktivitas setidaknya dilakukan dua kali pada setiap percobaan untuk mensimulasikan pengulangan.
Smartphone yang digunakan menggunakan accelerometer. Sinyal akselerasi dicatat pada frekuensi konstan $50 \mathrm{~Hz}$ yang cukup cepat untuk memperoleh informasi gerak tubuh manusia. Proses pelabelan dilakukan manual dengan memilih video yang direkam dari percobaan sebagai kebenaran dasar dan membandingkannya dengan file log dari sinyal inersia. 


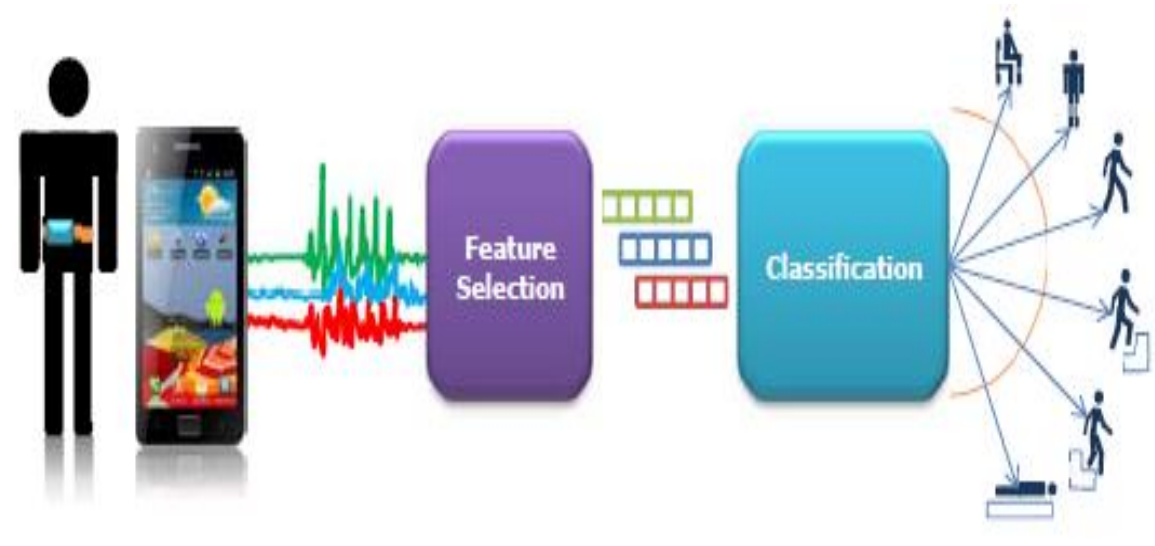

Gambar 8. Pipa Proses Activity Recognition

\section{HASIL DAN PEMBAHASAN}

Penelitian dengan judul "Energy Efficient Smartphone-Based Activity Recognition using Fixedpoint Arithmetic" [2] bertujuan untuk menerapkan aritmatika fixed-point untuk mengusulkan algoritma pembelajaran Multiclass Vector Machine yang dimodifikasi (SVM) yaitu dengan model Multiclass Hardware Friendly SVM (MC-HF-SVM) dengan dataset yang telah dibahas pada Bab 2. Berikut adalah langkah-langkah dalam model Multiclass HF-SVM (MC-HF-SVM):

1. Menyelesaikan masalah minimalisasi Constrained Quadratic Programming (CQP) dengan cara menggunakan Lagrange multipliers $\alpha$ i. Representasi tersebut mempunyai nama lain yaitu dual formulation dengan rumus yaitu:

$$
\begin{gathered}
\min _{\alpha} \frac{1}{2} \alpha^{T} Q \alpha-r^{T} \alpha \\
0 \leq \alpha_{i} \leq C \forall i \in[1, \ldots ., l], y^{T} \alpha=0
\end{gathered}
$$

Dimana Q adalah matriks kernel dan sebuah semidefinite positif simetris $1 \times 1$ matrix dimana qij $=\operatorname{yiyjK}(x i, x j)$.

2. Setelah didapatkan pola yang baru maka dapat dilakukan SVM Feed-Forward Phase (FFP) dengan rumus:

$$
f(x)=\sum_{i=1}^{l} y_{i} \alpha_{i} K\left(x_{i}, x\right)+b
$$

3. Kemudian karena adanya isu bahwa hasil yang diperoleh tidak valid dalam penggunaan fixedpoint arithmetic karena nilai $\alpha \mathrm{i}$ masuk ke dalam kelompok bilangan real yang dibatasi antara 0 dan $\mathrm{C}$, maka dilakukanlah proses normalisasi tanpa mempengaruhi tanda output dari classifier-nya tetapi justru besarnya dan membuat akurasi dari SVMnya tetap sama. Rumus normalisasinya yaitu:

$$
\beta_{i}=\alpha_{i} \frac{2^{k}-1}{C}
$$

4. Kemudian karena parameter dari dataset penelitian ini berupa integer dilakukanlah modifikasi rumus menjadi seperti berikut :

$$
\begin{gathered}
\min _{\beta} \frac{1}{2} \beta^{T} Q \beta-s^{T} \beta \text { s.t. } 0 \leq \beta_{i} \\
\leq \frac{2^{k}-1}{C} \forall i \epsilon[1, ., l]
\end{gathered}
$$

5. Untuk akhirnya memiliki FFP penuh dengan hanya nilai integer, perlu dilakukan pengubahan representasi dari kernel $\mathrm{K}(\cdot, \cdot)$ dan vektor input $\mathrm{x}$ dalam hal jumlah bit (u dan $\mathrm{v}$ bit masing-masing). Perubahan representasi ini menghasilkan rumus:

$$
\begin{gathered}
0 \leq K\left(x_{i}, x\right) \leq 1-2^{-u} \forall i \in[1, \ldots, l] \\
0 \leq x_{i} \leq 1-2^{-v} \forall i \in[1, \ldots, m]
\end{gathered}
$$

Jika digabungkan maka berikut rumus vektor fixed-point FPP yang sudah dimodifikasi :

$$
f(x)=\sum_{i=1}^{l} y_{i} \beta_{i} K\left(x_{i}, x\right)
$$

6. Untuk memperluas masalah biner menjadi masalah Multiclass, digunakan metode OVA untuk membandingkan masing-masing kelas c terhadap kelas-kelas lain, tetapi sebelumnya sebuah prosedur untuk memungkinkan perbandingan dalam kelompok pengklasifikasi SVM diperlukan. Hasilnya, dilakukan pengukuran perkiraan probabilitas 
untuk setiap PC SVM (x) dan memilih kelas aktual c* sebagai probabilitas output tertinggi untuk sampel uji yang diberikan

7. Kemudian probability estimation yang sudah didapatkan akan di implementasi menggunakan pendekatan dimana training set dan model SVM diberlakukan agar sesuai dengan nilai output FFP f (x) dengan fungsi sigmoid dari rumus berikut :

$$
p(x)=\frac{1}{1+e^{(\Gamma f(x)+\Delta)}}
$$

Dimana $\mathrm{p}(\mathrm{x})$ adalah perkiraan probabilitas, dan $\Gamma$ dan $\Delta$ adalah parameter fungsi yang dipasang dengan benar pada sampel pembelajaran yang tersedia.

8. Lalu dengan mempertimbangkan batasan aritmatik fixed-point, maka fungsi sigmoid yang juga bekerja dengan bilangan real, tidak dapat langsung digunakan untuk memperkirakan $\mathrm{p} \quad(\mathrm{x})$. Isu ini dapat diselesaikan dengan menggunakan Look-UpTables (LUTs). Pertama, sejumlah tetap bit $\mathrm{t}$ harus didefinisikan dan kemudian perkiraan probabilitas $\mathrm{p}(\mathrm{x})$ dapat dipetakan dengan $\mathrm{f}(\mathrm{x})$ tanpa perlu aritmatika floating-point. Proses MC-HF-SVM secara lengkap diilustrasikan dalam gambar 9 .

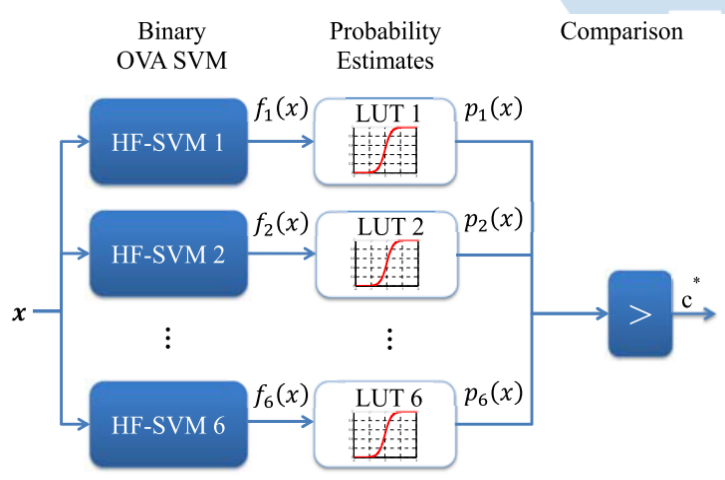

Gambar 9. MC-HF-SVM Menggunakan LUT Untuk Probability Estimates [2]
Kemudian dari langkah-langkah tersebut menunjukkan bahwa $\mathrm{t}=8$ adalah nilai yang cocok untuk aplikasi ini dan hanya dibutuhkan LUT dengan 256 elemen. Lalu dilakukan evaluasi dengan membandingkan hasil error rates dan hasil classification pada test data dari MC-HF-SVM dan MC-SVM. Berikut perbandingan hasil error rates yang didapatkan dari kedua pendekatan tersebut dengan range bits dari k antara 4 sampai 16 bits:

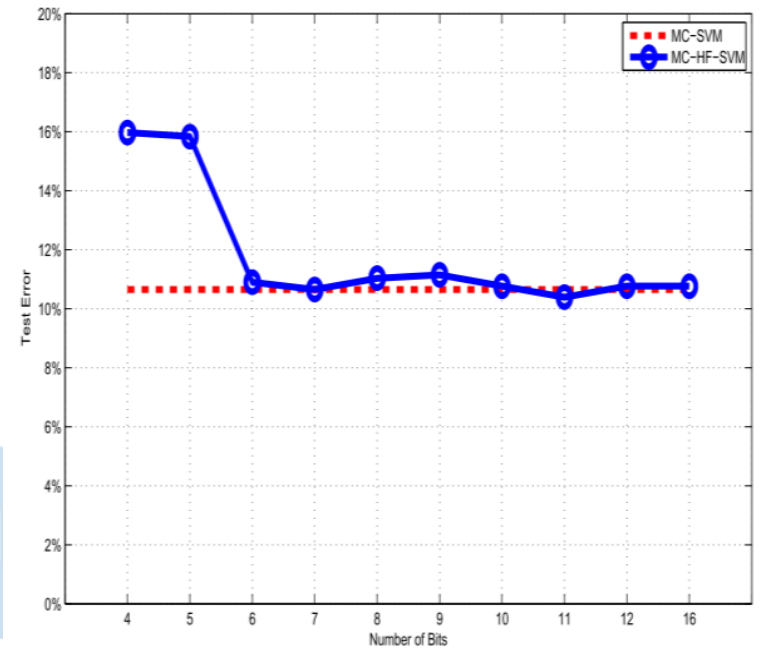

Gambar 17. Perbandingan Antara Tingkat Kesalahan yang Diperoleh Dengan MC-SVM (Garis Putus-Putus Merah) dan MC-HF-SVM (Garis Biru) Karena k Bervariasi [2]

Dari tes yang dilakukan pada bits ke 6 sampai 16 test error yang ada cukup stabil (hampir $1 \%$ variasi). Ketika test dilakukan pada bits dibawah 6 maka test error naik secara signifikan sebanyak kira-kira dua kali lipat. Selain itu, juga terlihat dari grafik bahwa beberapa test error dengan pendekatan fixed-point lebih kecil dari yang ditemukan dengan pendekatan MC-SVM Kemudian perbandingan hasil classification dari kedua pendekatan tersebut dengan menggunakan $\mathrm{k}=8$ bits dapat dilukiskan melalui tabel berikut:

Tabel 2. Confusion matrix Dari Hasil Classification Pada Test Data Menggunakan MC-SVM dan MC-HF-SVM

\begin{tabular}{|c|c|c|c|c|c|c|c|c|c|c|c|c|c|c|}
\hline Method & \multicolumn{7}{|c|}{ MC-SVM } & \multicolumn{7}{|c|}{ MC-HF-SVM $k=8$ bits } \\
\hline Activity & & 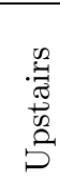 & 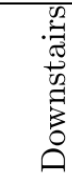 & 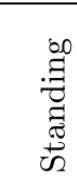 & 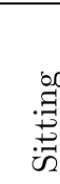 & 寄 & 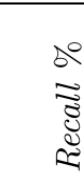 & 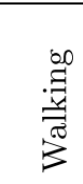 & 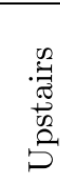 & חే & 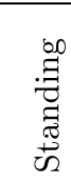 & & $\stackrel{d}{.]}$ & 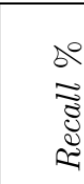 \\
\hline Walking & 109 & 0 & 5 & 0 & 0 & 0 & 95.6 & 109 & 2 & 3 & 0 & 0 & 0 & 95.6 \\
\hline Upstairs & 1 & 95 & 40 & 0 & 0 & 0 & 69.8 & 1 & 98 & 37 & 0 & 0 & 0 & 72.1 \\
\hline Downstairs & 15 & 9 & 119 & 0 & 0 & 0 & 83.2 & 15 & 14 & 114 & 0 & 0 & 0 & 79.7 \\
\hline Standing & 0 & 5 & 0 & 132 & 5 & 0 & 93.0 & 0 & 5 & 0 & 131 & 6 & 0 & 92.2 \\
\hline Sitting & 0 & 0 & 0 & 4 & 108 & 0 & 96.4 & 0 & 1 & 0 & 3 & 108 & 0 & 96.4 \\
\hline Laying & 0 & 0 & 0 & 0 & & 142 & 100 & 0 & 0 & 0 & 0 & & 142 & 100 \\
\hline Precision \% & 87.2 & 7.2 & 72.6 & 97.1 & $\overline{95.6}$ & 100 & 89.3 & 87.2 & 1.7 & 74.0 & 97.8 & 94.7 & 100 & 89.0 \\
\hline
\end{tabular}


(Sumber: Anguita, Ghio, Oneto, Llanas-Parra, \& Reyes-Ortiz, 2013)

Tabel 2. merupakan Confusion matrix dari hasil classification pada test data menggunakan traditional floating point MC-SVM (kiri) dan MC-HF-SVM dengan $\mathrm{k}=8$ bits (kanan). Baris mewakili kelas yang sebenarnya dan kolom mewakili kelas yang terprediksi. Angka yang di bold secara diagonal menunjukan jumlah sampel tes yang dengan benar diklasifikasikan. Pada tabel 2. dilakukan perbandingan yang mengukur keseluruhan dari accuracy, recall dan precision dari kedua pendekatan tersebut.

Variasi kecil diperhatikan dalam recognition accuracy dari aktivitas dinamis dalam dua pendekatan tersebut, seperti dalam kegiatan walking downstairs dan walking upstairs, yang juga menampilkan beberapa kesalahan classification terutama untuk kesamaan gerakan mereka. Aktivitas statis di sisi lain berkinerja lebih baik, seperti laying, classification error yang didapat sebesar $0 \%$. Selain itu, ada kesalahan klasifikasi kecil yang ditemukan antara standing dan sitting, yang dikaitkan dengan lokasi fisik telepon seluler pintar yang dipasang di pinggang dan kesulitan untuk membedakan di antara kedua aktivitas tersebut.

Hasil dari penelitian ini yaitu model Multiclass SVM standar yang dapat diubah dengan representasi fixed-point yang lebih efisien. Keuntungan dari penerapan model yang diusulkan dibandingkan dengan pendekatan tradisional SVM yang lain yaitu waktu proses yang lebih cepat, dan penggunaan sumber daya sistem yang lebih sedikit dimana hasilnya memberikan penghematan dalam konsumsi energi baterai perangkat dan juga kemungkinan untuk menggunakan pendekatan ini pada perangkat dengan harga murah (misalnya perangkat keras fixed-point).

\section{KESIMPULAN}

Sistem pengenalan aktivitas manusia dikembangkan sebagai bagian dari kerangka kerja untuk memungkinkan pemantauan terus menerus perilaku manusia di bidang kehidupan dibantu lingkungan, deteksi cedera olahraga, perawatan lansia, rehabilitasi, hiburan dan pengawasan di lingkungan rumah pintar. Proses pembelajaran mesin yang relevan adalah bagian yang paling menantang dari pengenalan aktivitas manusia yang dapat diaktifkan dan berdasarkan sensor. Metode yang digunakan juga berbagai macam dalam mengolah data.

Berdasarkan metode cara pembelajaran mengelola data aktivitas manusia, jika ingin dikembangkan teknologi ini bisa diterapkan pada:

1. Monitoring tahanan kota, tahanan kota yang ditahan tidak boleh meninggalkan satu kota yang menjadi tempat penahanannya. Pengawasannya, tahanan wajib melapor dua kali dalam seminggu. Dengan memberikan alat pendeteksi aktivitas manusia ini, membantu kepolisian dalam memonitoring keberadaan tahanan setiap waktu.

2. Monitoring Orang Tanpa Gejala (OTG) penderita COVID-19 yang melakukan isolasi mandiri. Dengan pengawasan ini, OTG dapat dipantau posisinya. Jika keluar dari area yang di ijinkan maka sensor pada smartwatch memberikan notifikasi peringatan awal atau memberitahukan tim medis yang bertanggung jawab dalam monitoring pasien yang melakukan isolasi mandiri.

3. Pendeteksian komunitas, adalah cara untuk memahami struktur jaringan yang kompleks, untuk akhirnya mengekstrak informasi yang berguna yang bisa didapatkan. Aplikasi beragam mulai dari perawatan, kesehatan, geografi regional, interaksi manusia, mobilitas hingga ekonomi [17][18].

4. Kepadatan kota dan peta distribusi, informasi yang diperoleh mengetahui titik dimana orang banyak berkumpul. Dari aktivitas yang mereka lakukan, kita dapat informasi bukan hanya gender, tetapi rentang usia, dan kapan tanggal aktivitas ini dilakukan. Pola yang didapatkan ini dapat digunakan untuk dijual kepada pelaku bisnis seperti Warunk Upnormal, Indomaret, Alfamart, pom bensin dan lain lain dalam membuka cabang baru.

5. Di tengah kondisi pandemi ini, kita bisa mendeteksi kerumunan padat suatu daerah sehingga bisa dicapai langkah awal pembubaran masa. Selain itu pendeteksian suhu, detak jantung, tekanan darah dan alat vital lainnya di tubuh manusia dapat diketahui dengan penggunaan sensor pada smartwatch dan terintegrasi pada smartphone. Mendeteksi alat vital pasien dengan menggunakan sensor dapat mengurangi kontak fisik antara pasien dengan dokter dan tim medis. Data alat vital pasien menjadi syarat awal ketika ingin melakukan pemeriksaan lebih lanjut. Pendeteksian ini juga bisa membantu mengurangi tingkat penyebaran virus COVID 19.

\section{DAFTAR PUSTAKA}

[1] A. T. Sahlol, P. Kollmannsberger, and A. A. Ewees, "Efficient Classification of White Blood Cell Leukemia with Improved Swarm Optimization of Deep Features," Sci. Rep., vol. 10, no. 1, pp. 1-11, 2020, doi: 10.1038/s41598-020-59215-9.

[2] Y. Lecun, Y. Bengio, and G. Hinton, "Deep learning," Nature, vol. 521, no. 7553, pp. 436-444, 2015, doi: 10.1038 /nature 14539

[3] A. S. Lundervold and A. Lundervold, "An overview of deep learning in medical imaging focusing on MRI," $Z$. Med. Phys., vol. 29, no. 2, pp. 102-127, 2019, doi: 10.1016/j.zemedi.2018.11.002.

[4] L. D. Nguyen, D. Lin, Z. Lin, and J. Cao, “Deep CNNs for microscopic image classification by exploiting transfer 
learning and feature concatenation," Proc. - IEEE Int Symp. Circuits Syst., vol. 2018-May, pp. 3-7, 2018, doi: 10.1109/ISCAS.2018.8351550.

[5] K. Simonyan and A. Zisserman, "Very deep convolutional networks for large-scale image recognition," 3 rd Int. Conf. Learn. Represent. ICLR 2015 - Conf. Track Proc., pp. 1$14,2015$.

[6] K. He, X. Zhang, S. Ren, and J. Sun, "Deep Residual learning for image recognition," Proc. IEEE Comput. Soc. Conf. Comput. Vis. Pattern Recognit., vol. 2016December, pp. 770-778, 2016, doi: 10.1109/CVPR.2016.90.

[7] C. Szegedy et al., "Going deeper with convolutions," Proc. IEEE Comput. Soc. Conf. Comput. Vis. Pattern Recognit., vol. 07-12-June-2015, pp. 1-9, 2015, doi: 10.1109/CVPR.2015.7298594.

[8] O. Russakovsky et al., "ImageNet Large Scale Visual Recognition Challenge," Int. J. Comput. Vis., vol. 115, no. 3, pp. 211-252, 2015, doi: 10.1007/s11263-015-0816-y.

[9] H. C. Shin et al., "Deep Convolutional Neural Networks for Computer-Aided Detection: CNN Architectures, Dataset Characteristics and Transfer learning," IEEE Trans. Med. Imaging, vol. 35, no. 5, pp. 1285-1298, 2016, doi: 10.1109/TMI.2016.2528162.

[10] T. Pansombut, S. Wikaisuksakul, K. Khongkraphan, and A. Phon-On, "Convolutional neural networks for recognition of lymphoblast cell images," Comput. Intell. Neurosci., vol. 2019, 2019, doi: 10.1155/2019/7519603.

[11] A. Çınar and S. A. Tuncer, "Classification of lymphocytes, monocytes, eosinophils, and neutrophils on white blood cells using hybrid Alexnet-GoogleNet-SVM," SN Appl. Sci., vol. 3, no. 4, pp. 1-11, 2021, doi: 10.1007/s42452021-04485-9.

[12] A. Kensert, P. J. Harrison, and O. Spjuth, "Transfer learning with Deep Convolutional Neural Networks for Classifying Cellular Morphological Changes," SLAS Discov., vol. 24, no. 4, pp. 466-475, 2019, doi: $10.1177 / 2472555218818756$

[13] H. M. Ahmad, S. Ghuffar, and K. Khurshid, "Classification of Breast Cancer Histology Images Using Transfer learning," Proc. 2019 16th Int. Bhurban Conf. Appl. Sci. Technol. IBCAST 2019, pp. 328-332, 2019, doi: 10.1109/IBCAST.2019.8667221.

[14] S. Hosseinzadeh Kassani and P. Hosseinzadeh Kassani, “A comparative study of deep learning architectures on melanoma detection," Tissue Cell, vol. 58, no. April, pp. 76-83, 2019, doi: 10.1016/j.tice.2019.04.009.

[15] V. Maeda-Gutiérrez et al., "Comparison of convolutional neural network architectures for classification of tomato plant diseases," Appl. Sci., vol. 10, no. 4, 2020, doi: 10.3390/app10041245.
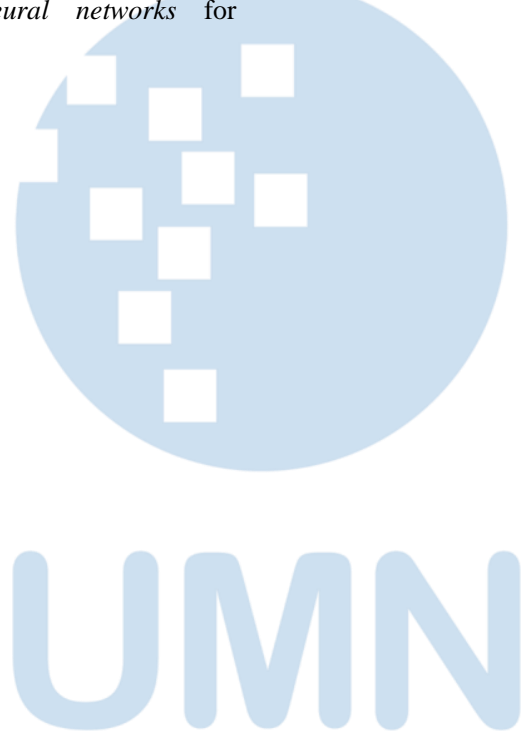